\title{
Molecular identification and mapping of a novel stripe rust resistance gene in wheat resistance line $\mathrm{CH5389}$
}

\author{
Haixian Zhan ${ }^{1}$ Huijuan Guo ${ }^{2}$ Linyi Qiao ${ }^{2}$ Liping Mao $^{3}$ Shuosheng Zhang ${ }^{*}$
}

\author{
${ }^{1}$ College of Chinese Materia Medica, Shanxi University of Chinese Medicine (SUCM), 030619, Jinzhong, China. E-mail: zhangshuosheng@aliyun.com. \\ ${ }^{*}$ Corresponding author. \\ ${ }^{2}$ Crop Science Institute, Shanxi Academy of Agricultural Sciences (SAAS), Taiyuan, China. \\ ${ }^{3}$ Vegetables Research Institute, Shanxi Academy of Agricultural Sciences (SAAS), Taiyuan, China.
}

ABSTRACT: Stripe rust, caused by Puccinia striiformis is one of the most destructive diseases of wheat worldwide. CH5389 is a wheatThinopyrum intermedium derived line conferring stripe rust resistance. Genetic analyses of seedlings of $F_{2}$ populations and $F_{2: 3}$ families developed by crossing CH5389 and susceptible common wheat revealed that stripe rust resistance in CH5389 was controlled by a single dominant gene that was designated YrCH5389. Eight SSR and EST-PCR polymorphic markers on chromosome 3AL were identified in F, population of CH5389/Taichung29. The YrCH5389 was flanked by EST marker BE405348 and SSR marker Xwmc388 on chromosome 3 AL with genetic distances of 2.2 and $4.6 \mathrm{cM}$, respectively. Comparative genomic analysis demonstrated that the orthologous genomic region of YrCH5389 covered $990 \mathrm{~kb}$ in rice, $640 \mathrm{~kb}$ in Brachypodium, and $890 \mathrm{~kb}$ in sorghum. Based on the locations of the markers, the resistance gene was located to chromosome deletion bin 3AL-0.85-1.00. Because there are no officially named stripe rust resistance genes on the $3 A L$ chromosome, the YrCH5389 should be designated as a new resistance gene. These linkage markers could be useful for marker-assisted selection in wheat resistance breeding.

Key words: stripe rust, genetic analysis, resistance gene, comparative genomic analysis, marker assisted selection.

Identificação e mapeamento de um novo gene de resistência a ferrugem linear na linhagem de trigo CH5389

RESUMO: A ferrugem linear causada por Puccinia striiformis é uma das doenças mais destrutivas do trigo no mundo. A linhagem CH5389 é derivada do cruzamento de trigo com Thinopyrum intermedium e confere resistência a ferrugem linear. Análises genéticas de indivíduos da população F2 e família F2:3 obtida a partir do cruzamento entre CH5389 e trigo comum suscetivel revelaram que a resistência à ferrugem linear na linhagem CH5389 foi controlada por um único gene dominante, designado YrCH5389. Oito marcadores polimórficos SSR e ESTPCR no cromossomo 3 AL foram identificados na população F2 de CH5389/Taichung29. O gene YrCH5389 foi delimitado pelos marcadores EST BE405348 e SSR Xwmc388 no cromossomo 3AL com distâncias genéticas de 2,2 e 4,6 cM, respectivamente. Análises genômicas comparativas demonstraram que regiões genômicas ortólogas do gene YrCH5389 compreendem $990 \mathrm{~kb}$ em arroz, $640 \mathrm{~kb}$ em braquipódio e $890 \mathrm{~kb}$ em sorgo. Com base nas localizações dos marcadores, o gene de resistência foi localizado no cromossomo 3 AL-0.85-1.00. Como não há genes oficialmente nomeados de resistência à ferrugem linear no cromossomo $3 \mathrm{AL}$, o YrCH5389 deve ser designado como um gene novo de resistência. Esses marcadores de ligação podem ser úteis para a seleção assistida de genótipos de trigo resistentes a ferrugem linear.

Palavras-chave: ferrugem linear, análise genética, gene de resistência, análise genômicas comparativas, seleção assistida por marcado.

\section{INTRODUCTION}

Wheat (Triticum aestivum L.) is one of the most important crops for humans. Stripe rust (yellow rust) caused by Puccinia striiformis Westend. f. sp. tritici Eriks. (Pst) is a devastating disease of wheat in cold and wet regions worldwide (CHEN, 2005). The disease has occurred in six pandemics and led to serious yield losses in China. The first epidemic of wheat stripe rust occurred in China in the 1950s. Subsequently, five pandemics occurred in 1964, 1990, 2002,2003 , and 2009, resulting in yield losses of 3.2 billion, 1.8 billion, 1.3 billion, 980 million, and 810 million kilograms, respectively (XIANG et al. 2016). Among the strategies for the control of wheat stripe rust, the most effective, economic, and environmentfriendly measure is the utilization and deployment of resistant varieties.

So far, more than 60 formally named stripe rust resistance genes $(\mathrm{Yr} 1-\mathrm{Yr} 78)$ and many temporarily designated have been reported in wheat and its wild relatives (XIANG et al. 2016; DONG et al. 2017). However, with the rapid evolution and spread of virulence of stripe rust pathogen populations, the major resistance genes are only effective for a limited period of time. In particular, the Pst races CYR32 and 
CYR33 prevented most of the stripe rust resistance genes from being effective in China (CHEN et al. 2005; YANG et al. 2003). Therefore, to reduce wheat yield losses caused by epidemics of stripe rust, the discovery of new sources conferring effective and durable resistance is urgently needed.

At present, molecular markers are widely used to identify wheat resistance genes. Of these, microsatellite (SSR) markers are extensively utilized in genetic mapping of wheat stripe rust resistance genes. Resistance genes $Y r 17, Y r 18, Y r 29, Y r 24 /$ Yr26, Yr36, Yr41, Yr43, Yr44, Yr45, Yr46, Yr47, $Y r 48, Y r 50$, and $Y r 76$ were identified and localized by SSR markers. For example, a high temperature adult plant (HTAP) QTL, QYrAlt.syau-3BS, was flanked on the short arm of chromosome 3B with SSR markers Xgwm389 and Xbarc238 (ZHAO et al. 2012). There was high collinearity between the genomes of wheat, rice, Brachypodium distachyon, and sorghum (DRAPER et al. 2001; PATERSON et al. 2009). Based on comparative genomics, Expressed sequence tag (EST)-SSR markers are an effective approach for producing molecular marker linkage maps of target genes (LI et al. 2006; LILLEMO et al. 2008; LIU et al. 2013; XIANG et al. 2016). Using EST-SSR markers analysis, genetic linkage maps of stripe rust gene $Y r 26$ and powdery mildew resistance gene Pm41 were located in wheat chromosome deletion $1 \mathrm{BL}$ bin $0.32-0.47$ and 3BL bin $0.63-1.00$, respectively (ZHANG et al. 2013; WANG et al. 2014).

CH5389 is a new wheat Thinopyrum intermedium derived line. It is immune to five Pst races CYR31, CYR32, CYR33, SY11-5, and CYR34. Here, we identify the new stripe rust resistance gene and construct a comparative genomic linkage map using SSR markers and ESTSSR markers in the wheat line.

\section{MATERIALS AND METHODS}

\section{Materials and populations}

CH5389 is a wheat-Th. intermedium line derived from crossing Jingchun 5/TAI7045//7621696. Resistant donor TAI7045 of CH5389, a wheatTh. intermedium partial amphiploid with 56 chromosomes, exhibited immune responses to stripe rust and powdery mildew. The resistant parent CH5389 is resistance, whereas, the susceptible wheat cultivars/lines SY95-71, Taichung 29 and Mianyang 11 are all susceptible to stripe rust.

To examine the inheritance of stripe rust resistance, $F_{1}$ and $F_{2}$ plants derived from the cross CH5389/SY95-71, CH5389/Taichung 29, and Mianyang 11/CH5389 were used to construct segregating populations. The one hundred fifty-five $\mathrm{F}_{2: 3}$ families of CH5389/ Taichung 29 were further used for genetic analyses. The susceptible control was Chuanyu 12. The TAI7045, CH5389, SY95-71, Taichung 29, Mianyang 11, and Chuanyu 12 were maintained by Shanxi Academy of Agricultural Sciences. The Chinese Spring nullisomic-tetrasomic and ditelosomic stocks were obtained from the Wheat Genetic and Genomic Resource Center, Kansas State University.

\section{Disease evaluation}

Approximately 30 seeds of Th. intermedium, TAI7045, and 7 wheat cultivars/ lines (76216-96, Jing 411, Taiyuan768, Jinchun 5, CH5389, Taichung 29, SY95-71, and Chuanyu 12) were planted in $10 \mathrm{~cm}$ pots in controlled greenhouse for seedling resistance evaluation using five $P s t$ races CYR31, CYR32, CYR33, SY11-5, and CYR34. The first leaf fully expanded, seedlings were artificially inoculated with fresh spores of the Pst races. Inoculated plants were incubated at 9-11 ${ }^{\circ} \mathrm{C}$ in $100 \%$ relative humidity without light for $24 \mathrm{~h}$. Seedlings were then transferred into a greenhouse with $16 \mathrm{~h}$ of light and $8 \mathrm{~h}$ of darkness with a diurnal temperature cycle of $17^{\circ} \mathrm{C}$ and $12{ }^{\circ} \mathrm{C}$, respectively. When Chuanyu 12 was heavily infected, stripe rust reactions were recorded on individual plants or lines about 20 days after inoculation. Infection type (IT) was based on $0-4$ scale system, plants with ITs of $0-2$ were considered to be resistant and those with IT 3-4 were determined to be susceptible.

Seedling of parents, all $\mathrm{F}_{1}, \mathrm{~F}_{2}$, and $\mathrm{F}_{2: 3}$ plants were grown in controlled greenhouse. Twenty seeds of each parent and $\mathrm{F}_{1}$ generations, about 200 seeds of the $F_{2}$ population and 15 seeds for each of the $\mathrm{F}_{2: 3}$ lines were randomly sown in large pots $(54 \times 27 \times 20 \mathrm{~cm})$. Race CYR32 was used to evaluate seedling resistance of all plants with the same method mention above.

\section{Molecular marker analysis}

Total genomic DNA of parents and $\mathrm{F}_{2}$ individuals was extracted from uninfected seedling leaves. Bulk DNA was obtained by combining equal amounts of DNA from 10 resistant (IT 0) and 10 susceptible (IT 4) $\mathrm{F}_{2}$ plants derived from CH5389/ Taichung 29. Six hundred and nineteen SSR primers distributed across the A, B and D genomes and 52 EST-STS markers were used to screen polymorphisms in the two parents and bulk DNA from resistant and susceptible plants. 
PCR was conducted in total volumes of 15 $\mu \mathrm{l}$ containing $50 \mathrm{ng}$ genomic DNA, $0.25 \mathrm{mM}$ each of the primers, $0.3 \mathrm{mM}$ dNTPs, $1 \times$ PCR Buffer, and 0.75U Taq DNA polymerase (LI. 2011). The PCR was performed at $94{ }^{\circ} \mathrm{C}$ for $5 \mathrm{~min}$; followed by 34 cycles of $94{ }^{\circ} \mathrm{C}$ for $1 \mathrm{~min}$; 50,55 , or $60{ }^{\circ} \mathrm{C}$ (depending on the individual primers) for $30 \mathrm{~s} ; 72^{\circ} \mathrm{C}$ for $1 \mathrm{~min}$; and a final incubation at $72{ }^{\circ} \mathrm{C}$ for $5 \mathrm{~min}$. The amplification products were analyzed by separation on $8 \%$ nondenaturing polyacrylamide gels with $1 \times \mathrm{TBE}$ buffer and visualized by silver staining.

\section{Statistical analysis}

Chi-square tests were used to determine the goodness of fit of observed and expected segregation in the $F_{1}, F_{2}$, and $F_{2: 3}$ populations. Linkage analysis between linked markers and the resistance gene was performed using the JoinMap 4.0 software and recombination values were calculated using the Kosambi mapping function (KOSAMBI. 1944).

\section{RESULTS AND DISCUSSION}

\section{Stripe rust responses}

Seedling IT data showed that CH5389, resistance donor TAI7045, and wild parent $T h$. Intermedium were resistant to five Pst races CYR31, CYR32, CYR33, SY11 and CYR34 (IT 0-2), whereas the wheat parents (76216-96, Jing 411, Taiyuan 768, and Jinchun 5) were susceptible to five Pst races (IT 3-4). Taichung 29 was only resistant to the new virulent Pst race CYR34 (Table 1). These results suggested that CH5389 probably contained one or more resistance genes to stripe rust.

CH5389 was resistant, while SY95-71, Taichung 29, and Mianyang 11 were highly susceptible to CYR32 in the seeding stage. All $F_{1}$ plants of the three reciprocal crosses showed resistance similar to that of the resistant parent, indicating that the resistance gene was dominant in CH5389 (Table 2). Among the 167 plants from the CH5389/Taichung 29 $\mathrm{F}_{2}$ population, 119 plants were resistant and 48 plants were susceptible to Pst race CYR32. Segregation of resistance was consistent with a ratio of $3: 1\left(\chi^{2}=1.25\right.$, $\mathrm{P}=0.26$ ). The $\mathrm{F}_{2}$ population of Mianyang11/CH5389 segregated into 97 resistant and 40 susceptible individuals, fitting the $3: 1$ ratio $\left(\chi^{2}=1.29, \mathrm{P}=0.26\right)$. In another 187 test plants from the CH5389/SY95$71 \mathrm{~F}_{2}$ population, the segregation ratio of resistance to susceptibility was $3: 1\left(\chi^{2}=0.29, \mathrm{P}=0.59\right)$ (Table 2$)$. One hundred and fifty-five $\mathrm{F}_{2: 3}$ lines were obtained when $167 \mathrm{~F}_{2}$ plants were transplanted to the field. In $\mathrm{F}_{2: 3}$ families, the segregation ratio was 41 homozygous resistant (RR): 77 segregating (Rr): 37 homozygous susceptible (rr), which was consistent with an expected 1:2:1 ratio $\left(\chi^{2}=1.95, \mathrm{P}=0.16\right)$. All finding indicated that the resistance to CYR32 was controlled by a single dominant gene in $\mathrm{CH} 5389$. The gene was designated temporarily as $\mathrm{YrCH5389}$ (Table 3).

Identification of markers linked to the stripe rust resistance gene

To determine the chromosomal location of the stripe rust resistance gene $\mathrm{YrCH}$ 5389, a total of 619 pairs of SSR markers from the entire wheat genome were utilized. Of these, 394 markers amplified polymorphisms between the resistant and susceptible parents. Six markers (Xgwm666, Xwmc173, Xwmc388, Xwmc594,Xwmc215, and Xgwm 497) were polymorphic between the resistant and susceptible bulk DNA samples as well as the parents $\mathrm{CH} 5389$ and Taichung 29. The $\mathrm{F}_{2}$ mapping population from the $\mathrm{CH} 5389 \times$ Taichung 29 cross was genotyped with the six polymorphic markers. All primers are co-dominant markers except for Xwmc388 and Xgwm497. Results demonstrated that six primers were linked to $\mathrm{YrCH} 3389$ with genetic distances ranging from 4.6 to $45.8 \mathrm{cM}$ (Figure 1, Figure 3). Of the six markers linked to $\mathrm{YrCH} 5389$, Xgwm666, Xwmc594, and Xwmc388 were previously mapped to wheat chromosome arm $3 \mathrm{AL}, X w m c 173$ was located in 1D, 3A, 4A, and 5A, Xwmc215 was assigned to $5 \mathrm{D}, 3 \mathrm{~A}$, and $5 \mathrm{~A}$, and $\mathrm{Xgwm} 497$ was mapped to $1 \mathrm{~A}, 2 \mathrm{~A}, 3 \mathrm{~A}, 3 \mathrm{D}$, and 5B (SOMERS et al. 2004). To verify the location of $\mathrm{YrCH} 5389$, these markers were further examined in CS nullitetrasomic and ditelosomic lines. Six microsatellite markers amplified the specific bands in CS and the CS nulli-tetrasomic lines, N3BT3A, N3DT3B, and Dt3AL, but no expected bands were produced in the nulli-tetrasomic N3AT3B, N3AT3D, and Dt3AS lines (Figure 2). Results clearly validated that the location of the resistance gene $\mathrm{YrCH} 3389$ was in the long arm of chromosome $3 \mathrm{~A}$.

The Xgwm 666 and Xwmc388 markers were mapped $14 \mathrm{cM}$ and $4.6 \mathrm{cM}$, respectively, away from the resistance gene $\mathrm{YrCH}$ 5389. Because the markers were previously assigned to the $3 \mathrm{AL}-8$ deletion bin FL 0.85-1.00, we designed the EST-STS markers based on wheat EST and orthologous regions of rice. Eight markers, linked to stem rust resistance gene Sr35, were also developed (ZHANG et al. 2010). These markers were further tested for polymorphisms between susceptible and resistant lines. Among the EST-STS primers, two primers, BE405348 and CV775292, were also linked to $\mathrm{YrCH5389.} \mathrm{Based}$ 
Table 1 - Resistance to five Pst races in CH5389 and its parents.

\begin{tabular}{|c|c|c|c|c|c|c|c|}
\hline Line & $2 n=$ & genome & CYR31 & CYR32 & CYR33 & SY11 & CYR34 \\
\hline Th.IntermedIium & 42 & $\mathrm{SJJ}^{\mathrm{s}}$ & 0 & 0 & 0 & 0 & 0 \\
\hline TAI 7045 & 56 & $\mathrm{ABDS}+\mathrm{J}^{\mathrm{s}}$ & 0 & 0 & 0 & 0 & 0 \\
\hline $76216-96^{a}$ & 42 & $\mathrm{ABD}$ & 3 & 4 & 4 & 4 & 4 \\
\hline Jing $411^{\mathrm{a}}$ & 42 & $\mathrm{ABD}$ & 3 & 4 & 3 & 4 & 4 \\
\hline Taiyuan $768^{\mathrm{b}}$ & 42 & $\mathrm{ABD}$ & 3 & 4 & 4 & 3 & 4 \\
\hline Jinchun $5^{\mathrm{b}}$ & 42 & $\mathrm{ABD}$ & 4 & 4 & 4 & 4 & 4 \\
\hline CH5389 & 42 & $\mathrm{ABD}$ & 0 & 0 & 0 & 0 & 0 \\
\hline Taichung29 & 42 & $\mathrm{ABD}$ & 4 & 4 & 4 & 4 & 0 \\
\hline SY95-71 & 42 & $\mathrm{ABD}$ & 4 & 4 & 3 & 4 & 4 \\
\hline Mianyang 11 & 42 & $\mathrm{ABD}$ & 4 & 4 & 4 & 4 & 3 \\
\hline
\end{tabular}

${ }^{\mathrm{a}}$ The wheat parents of TAI7045. ${ }^{\mathrm{b}}$ The wheat parents of CH5389.

on these molecular markers, $\mathrm{YrCH} 3389$ was located to deletion bin 3AL $0.85-1.00$ and was flanked by markers BE405348 and Xwmc388 at genetic distances of 2.2 and $4.6 \mathrm{cM}$, respectively.

\section{Comparative genomics analysis}

The wheat $3 \mathrm{AL}$ region of stripe rust resistance gene $\mathrm{YrCH} 5389$ had the same gene order to rice 1, Brachypodium 2, and sorghum 3. BE405348 was orthologous to rice, Brachypodium, and sorghum genes Os01g72240, Bd2g60930, and Sb03g045930, respectively. The marker CV775292 was linked to the homologous genes of rice, Brachypodium, and sorghum, Os01g73230, Bd2g61570, and Sb03g046820, respectively. Thus, the orthologous genomic region of $\mathrm{YrCH} 5389$ covered $990 \mathrm{~kb}$ in rice $(O s 01 g 72240$ to $O s 01 g 73230), 640 \mathrm{~kb}$ in
Brachypodium (Bd2g60930 to Bd2g61570), and

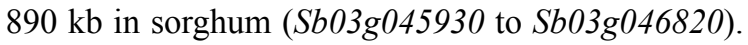
Orthologous genomic regions of $\mathrm{YrCH} 5389$ in rice, Brachypodium, and sorghum genomes will be useful for the fine mapping of $\mathrm{YrCH} 3389$.

With the appearance of new Pst races, most stripe rust resistance genes have become ineffective. For example, since the prevalence of Pst race CYR29, many wheat cultivars with resistance gene $\operatorname{Yr} 9$ lost resistance in China (Wan et al. 2004). Similarly, the newly identified Pst race CYR34 overcame the resistance of the $Y r 24 / Y r 26$ polymerization gene in wheat variety Cuanmai42 (LIU et al. 2010). Thus, it is essential to explore new stripe rust resistance genes for wheat breeding. In this study, we investigated the resistance gene in wheat line CH5389. Genetic analysis indicated that the stripe rust resistance in

Table 2 - Genetic analysis of resistance for stripe rust reactions in parents and $F_{1}, F_{2}$ populations.

\begin{tabular}{|c|c|c|c|c|c|c|c|}
\hline Parent or cross & Generation & Number of tested & Resistant & Susceptible & Expected ratio & $\chi^{2}$-value & Probability \\
\hline CH5389 & $\mathrm{P}_{1}$ & 19 & 19 & & & & \\
\hline SY95-71 & $\mathrm{P}_{2}$ & 18 & & 18 & & & \\
\hline Taichung29 & $\mathrm{P}_{3}$ & 16 & & 16 & & & \\
\hline Mianyang 11 & $\mathrm{P}_{4}$ & 17 & & 17 & & & \\
\hline \multirow[t]{2}{*}{ CH5389/Taichung29 } & $\mathrm{F}_{1}$ & 17 & 17 & 0 & $1: 0$ & & \\
\hline & $\mathrm{F}_{2}$ & 167 & 119 & 48 & $3: 1$ & 1.25 & 0.26 \\
\hline \multirow[t]{2}{*}{ Mianyang 11/CH5389 } & $\mathrm{F}_{1}$ & 18 & 18 & 0 & $1: 0$ & & \\
\hline & $\mathrm{F}_{2}$ & 137 & 97 & 40 & $3: 1$ & 1.29 & 0.26 \\
\hline \multirow[t]{2}{*}{ CH5389/SY95-71 } & $\mathrm{F}_{1}$ & 16 & 16 & 0 & $1: 0$ & & \\
\hline & $\mathrm{F}_{2}$ & 187 & 137 & 50 & $3: 1$ & 0.29 & 0.59 \\
\hline
\end{tabular}

Ciência Rural, v.48, n.5, 2018. 
Table 3 - resistance segregation to stripe rust race CYR32 in the $\mathrm{F}_{3}$ lines.

\begin{tabular}{|c|c|c|c|c|c|c|}
\hline & \multicolumn{2}{|c|}{--------------F } & \multicolumn{2}{|c|}{-------F plants------- } & \multirow[b]{2}{*}{$\chi^{2}$-value $(3: 1)$} & \multirow[b]{2}{*}{ Probability } \\
\hline & Observed & Expected & $\mathrm{R}$ & $\mathrm{S}$ & & \\
\hline YrYr HR & 41 & 38.25 & 731 & 0 & & \\
\hline Yryr Seg & 77 & 77.5 & 902 & 273 & 1.95 & 0.16 \\
\hline Yryr HS & 37 & 38.25 & 0 & 556 & & \\
\hline Total & \multicolumn{2}{|c|}{155} & & & & \\
\hline$\chi^{2}$-value $(1: 2: 1)$ & \multicolumn{2}{|c|}{0.24} & & & & \\
\hline Probability & \multicolumn{2}{|c|}{0.89} & & & & \\
\hline
\end{tabular}

line CH5389 was controlled by a dominant gene $\mathrm{YrCH} 5389$.

The stripe rust resistance gene $\operatorname{Yr} 76$ has been mapped on the short arm of chromosome $3 \mathrm{~A}$ (XIANG et al. 2016). In our study, $\mathrm{YrCH} 5389$ was located in the $3 \mathrm{AL}$ chromosome. Tyee carrying Yr76 was resistant to races PSTV37, PSTV40, and PSTV79, while CH5389 was effective against Puccinia striiformis f. sp. tritici (Bgt) isolates CYR31, CYR32, CYR33, SY11, and PSTV26. This finding verified that $\mathrm{YrCH} 3389$ was different from stripe rust resistance gene $\operatorname{Yr} 76$. To date, no stripe rust resistance gene was previously located on $3 \mathrm{AL}$ chromosome. There were five quantitative trait loci (QTL) QYrst. orr-3AL, QYrdr.wgp-3AL, QyrPI182103.wgp-3AL, QYr.cau-3AL, and QYr.cim-3A in chromosome 3AL. Among these QTL, QYrst.orr-3AL accounted for $6 \%$ of the phenotypic variations. The QYrdr.wgp-3AL was located by marker IWA6834, explaining 1.78-13.85\% of the phenotypic variations, and QyrPI182103.wgp$3 A L$ was maped with markers IWA899 and Xgwm2, accounted for $5.4 \%-8.1 \%$ of the phenotypic variance (ROSEWAME et al. 2010; YUAN et al. 2013). Because all of the stripe rust resistant QTL belonged to minor quantitative resistance, $\mathrm{YrCH} 5389$ was likely a new gene for stripe rust resistance.

Micro-collinearity of the $\mathrm{YrCH} 3389$ genomic region in rice, Brachypodium, and sorghum

Studies have shown that the homologous regions of wheat, rice, Brachypodium, and sorghum genomes are powerful tool for constructing genetic linkage maps. The powdery mildew resistant genes, Pm36, Pm41, Pm51, and MlIW170, and the stripe rust

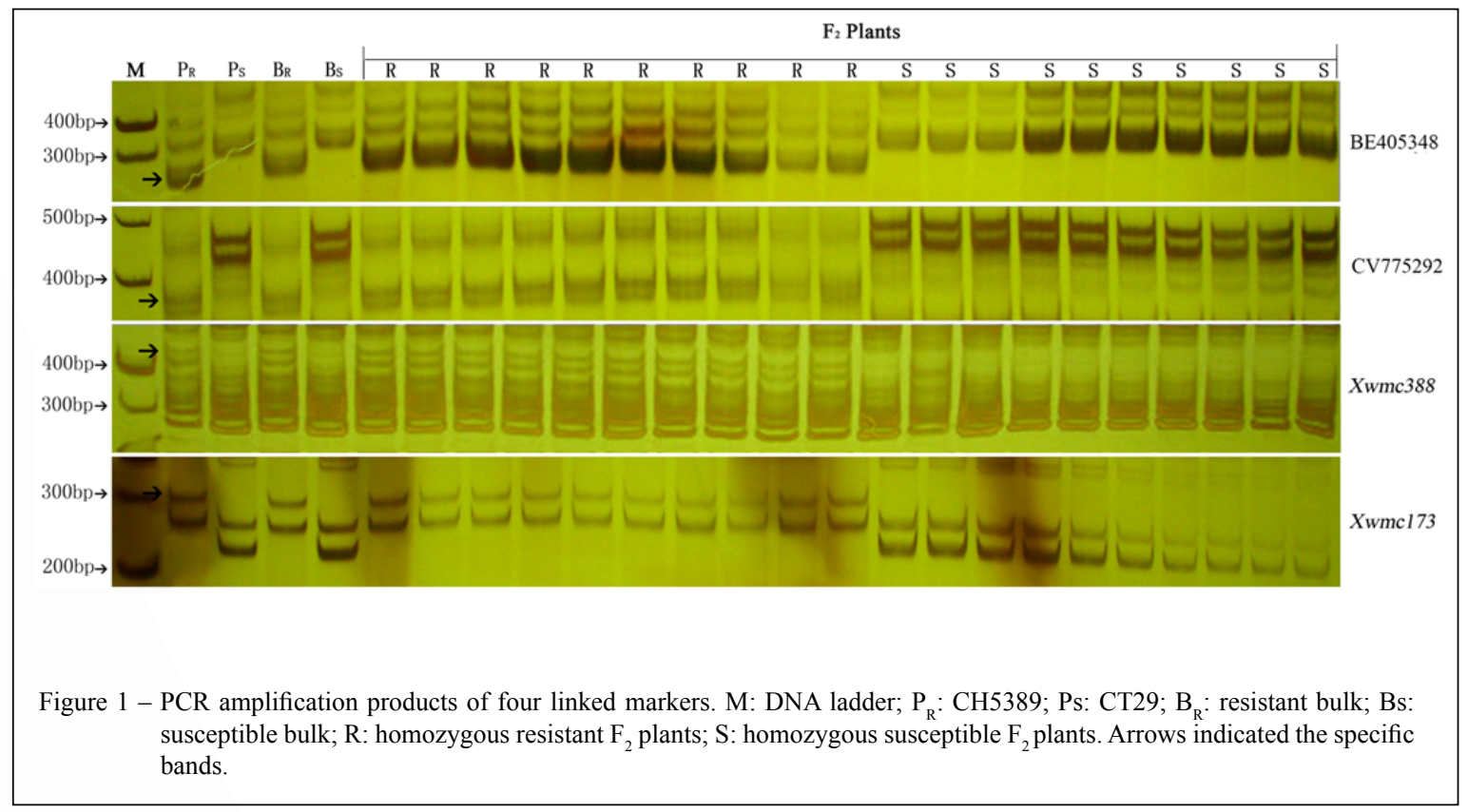

Ciência Rural, v.48, n.5, 2018. 


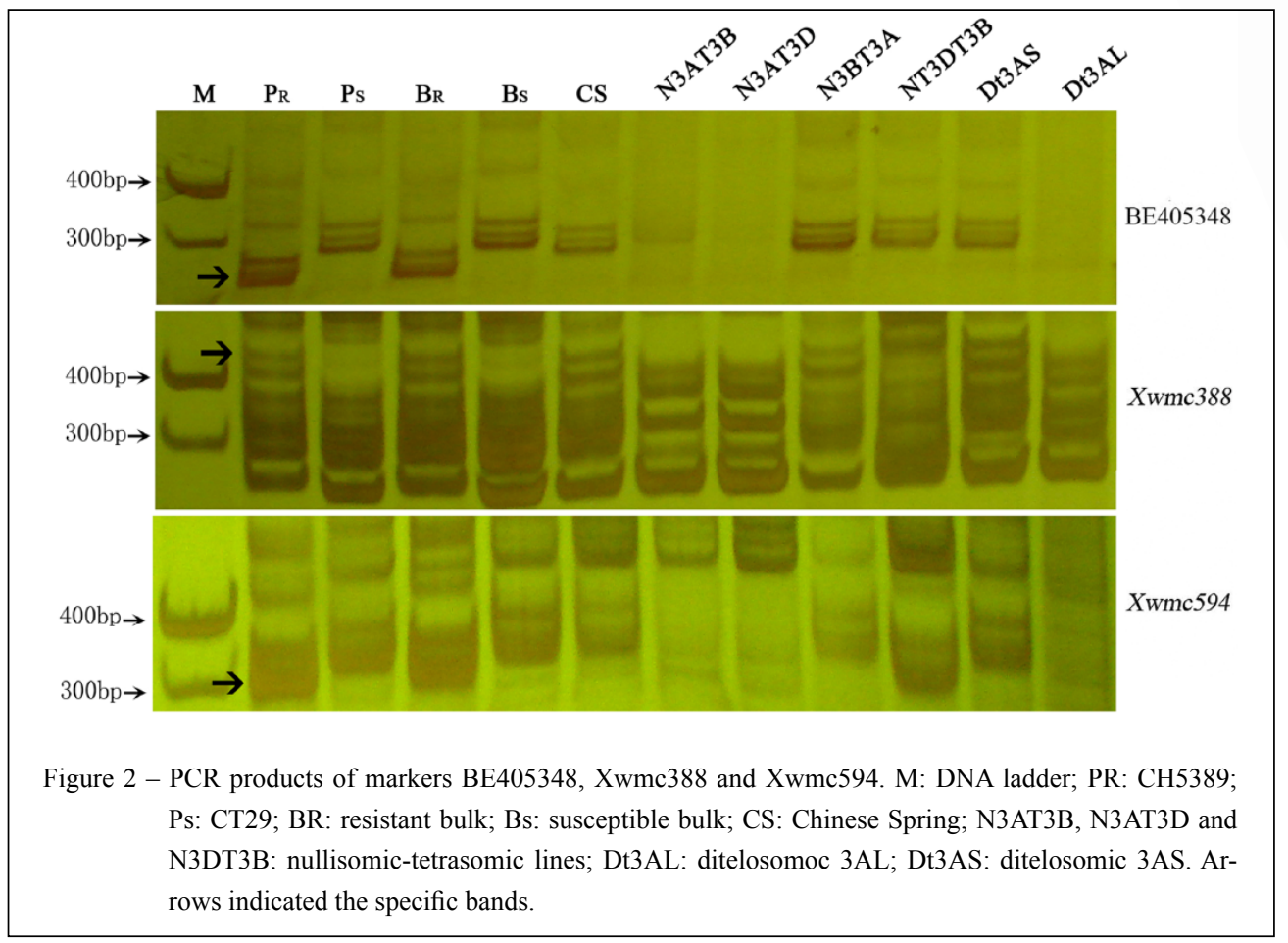

resistant gene $\operatorname{Yr} 26$ were identified by comparative genomics analysis, and linkage markers were also designed using the collinear regions in wheat, rice, Brachypodium, and sorghum (ZHANG et al. 2013; WANG et al. 2014; ZHAN et al. 2014). In the current study, collinearity was observed between wheat, rice, Brachypodium, and sorghum in the $\mathrm{YrCH} 5389$ genomic region. Two linked markers, BE405348 and CV775292, were developed to construct the genetic linkage map of CH5389. Comparative genomic analysis showed that the orthologous genomic region of $\mathrm{YrCH} 5389$ covered $990 \mathrm{~kb}$ in rice, $640 \mathrm{~kb}$ in Brachypodium, and $890 \mathrm{~kb}$ in sorghum. The recently published genome data of wild emmer and Aegilops

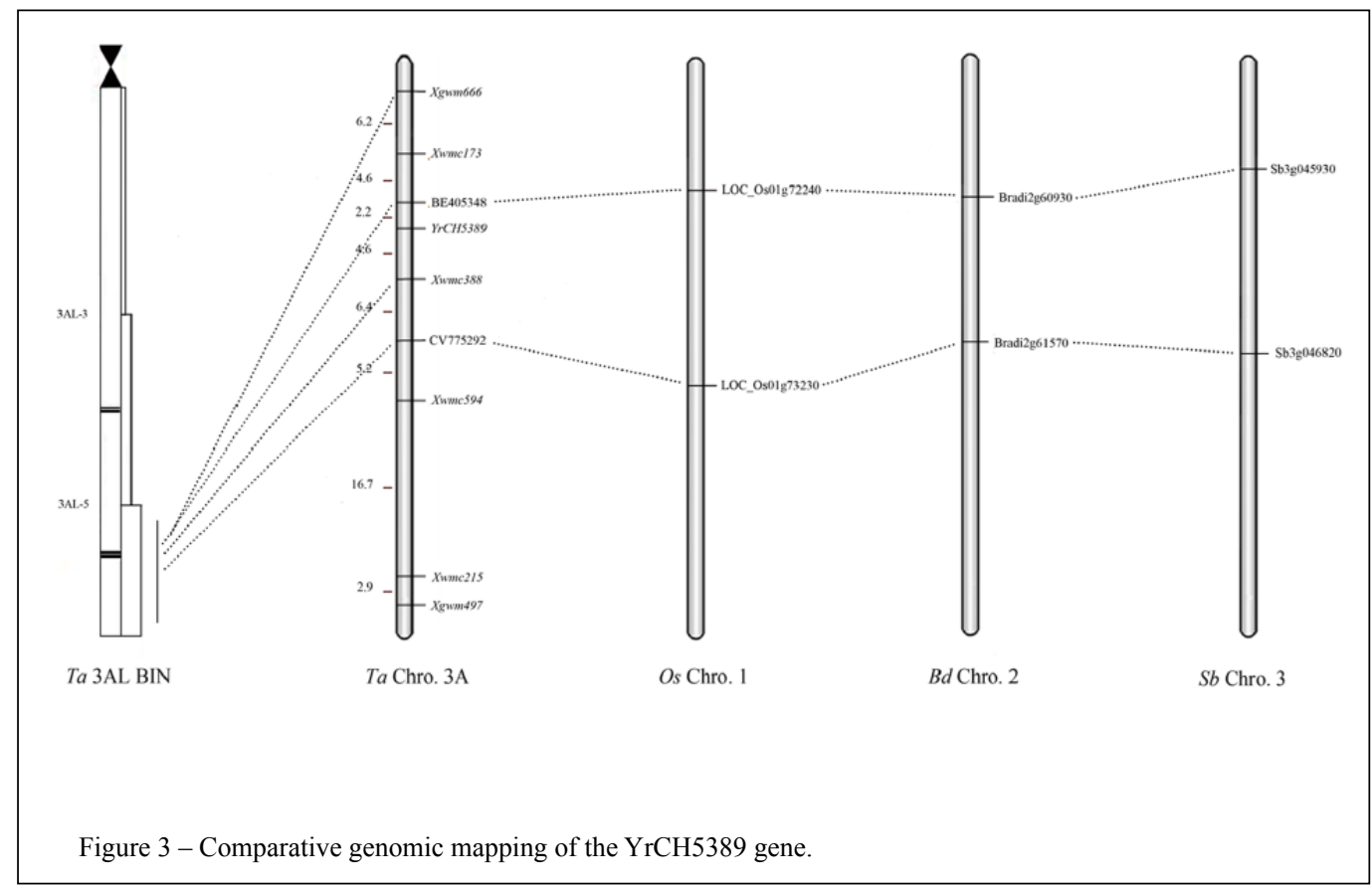

Ciência Rural, v.48, n.5, 2018. 
tauschii provide more information for identification of resistance genes (JIA et al. 2013; AVNI et al. 2017). The publication of wheat genome data could benefit further development of fine genetic linkage maps for stripe rust resistant gene $\mathrm{YrCH} 3389$ (CALLAWAY 2017).

\section{Marker-assisted selection (MAS)}

The MAS was a useful tool for the specific tracking of many traits in wheat germplasm resources, such as disease resistance and drought tolerance (ELSAYED et al. 2012). Through the identification of tightly linked markers, we detected the presence of target genes and select target traits. The nearest marker linked to stripe rust resistance gene $\mathrm{Yr} 15$ could distinguish between resistant and susceptible parents, accordingly, the marker was the best tool for MAS of $\operatorname{Yr} 15$ (YANIV et al. 2015). In order to acquire more durable resistance, the linked markers of powdery mildew resistance gene $P m 51$ were used to diagnose other resistance genes. The primer A-8, amplified specific bands associated with drought tolerance in bread wheat Giza-168 and Sham-6, was used to select tolerant genotypes in wheat breeding (ELSAYED et al. 2012). Based on the linkage map, we found that $\mathrm{YrCH} 5389$ was flanked by markers BE405348 and Xwmc388 with 2.2 and $4.6 \mathrm{cM}$ genetic distances, respectively. All the examples above illustrated that BE405348 could be used for markerassisted selection of $\mathrm{YrCH} 5389$ to produce resistant wheat cultivars.

\section{CONCLUSION}

The wheat line CH5389 showed outstanding resistance to the prevalent races of stripe rust. Genetic and molecular markers analyses identified that resistance gene $\mathrm{YrCH} 5389$ was located to chromosome deletion bin 3AL-0.85-1.00. The CH5389 should be used as a new source of resistance for breeding wheat resistant to stripe rust.

\section{ACKNOWLEDGMENTS}

This project was funded by National Natural Science Foundation of China (31601303), Shanxi Province International Cooperation Project (201603D421003), the Foundation for Youths of Institute of Crop Science, Shanxi Academy of Agricultural Sciences (ZZQ1701)

\section{REFERENCES}

AVNI, R. et al. Wild emmer genome architecture and diversity elucidate wheat evolution and domestication. Science, v.357, p.93-97, 2017. Available from: <http://science.sciencemag.org/ content/357/6346/93.long > . Accessed: Jul. 7, 2017, doi: 10.1126/ science.aan 0032 .

CALLAWAY, E. Small group scoops international effort to sequence huge wheat genome. Nature, v.31, p.22924, 2017. Available from: $<\mathrm{http}$ ://dx.doi.org/10.1038>. Accessed: Otc. 31, 2017, doi: 10.1038

CHEN, X.M. Epidemiology and control of stripe rust [Puccinia striiformis f. sp. tritici] on wheat. Canadian Journal of Plant Pathology, v.27, p.314-337, 2005. Available from: <http:// dx.doi. org/10.1080/07060660509507230>. Accessed: Jul. 01, 2005, doi: $10.1080 / 07060660509507230$

CHEN, W.Q. et al. Race dynamics, diversity, and virulence evolution in Puccinia stiifor-mis f. sp. tritici, the causal agent of wheat stripe rust in China from 2003 to 2007. Plant Disease, v.93, p.1093-1101, 2009. Available from: <http://www.jstor.org/ stable/4280223>. Accessed: Nov. 1, 2009, doi: 10.1094/PDIS-9311-1093.

DRAPER, J. et al. Brachypodium distachyon: a new model system for functional genomics in grasses. Plant Physiology, v.127, p.1539-1555, 2001. Available from: <http://www.jstor.org/ stable/4280223>. Accessed: Dec. 4, 2001, doi: 10.1104/pp.010196.

DONG, Z.Z. et al. Validation and characterization of a QTL for adult plant resistance to stripe rust on wheat chromosome arm 6BS (Yr78). Theoretical and Applied Genetics, v.130, p.2127-2137, 2017. Available from: $<$ http://dx.doi.org/10.1007/s00122-017-29469>. Accessed: Jul. 19, 2017, doi: 10.1007/s00122-017-2946-9.

ELSAYED, A.I. et al. Molecular marker assisted for recognition drought tolerant in some of bread wheat genotypes. Journal of Agronomy and Crop Science, v.15, p.17-23, 2012. Available from: <http://dx.doi.org/10.1007/s12892-011-0051-1>. Accessed: Jul. 19, 2017, doi: 10.1007/s12892-011-0051-1.

JIA, J.Z. et al. Aegilops tauschii draft genome sequence reveals a gene repertoire for wheat adaptation. Nature, v.496, p.91-95, 2013. Available from: <http:// dx.doi.org/10.1038/ nature12028>. Accessed: Jul. 19, 2017, doi: 10.1038/nature12028.

KOSAMBI, D.D. The estimation of map distances from recombination values. Annals of Human Genetics, v.12, p.172-175, 1943. Available from: <http:// dx.doi. org/10.1111/j.1469-1809.1943. tb02321.x>. Accessed: Jan. 01, 1943, doi: 10.1111/j.1469-1809.1943.tb02321.x.

LI, G.Q. et al. Molecular mapping of stripe rust resistance gene $\mathrm{YrCH}_{4} 2$ in Chinese wheat cultivar Chuanmai42 and its allelism with $Y r 24$ and $Y r 26$. Theoretical and Applied Genetics, v.112, p.1434-1440, 2006. Available from: <http:// dx.doi.org/10.1007/ s00122-006-0245-y >. Accessed: Mar. 9, 2006, doi: 10.1007/ s00122-006-0245-y.

LI, Q. et al. $Y r 45$, a new wheat gene for stripe rust resistance on the long arm of chromosome 3D. Theoretical and Applied Genetics, v.122, p.189-197, 2011. Available from: < http:// dx. Doi. org/10.1007/s00122-010-1435-1>. Accessed: Jan. 1, 2011, doi: $10.1007 / \mathrm{s} 00122-010-1435-1$

LILLEMO, M. et al. The adult plant rust resistance loci $L r 34 / Y r 18$ and $L r 46 / Y r 29$ are important determinants of partial resistance to powdery mildew in bread wheat line Saar. Theoretical and Applied Genetics, v.116, p.1155-1166, 2008. Available from: 
$<$ http:// dx.doi.org/ 10.1007/s00122-008-0743-1 > . Accessed: Mar. 18, 2008, doi: 10.1007/s00122-008-0743-1.

LIU, J, et al. Putative Thinopyrum intermedium-derived stripe rust resistance gene Yr50 maps on wheat chromosome arm 4BL. Theoretical and Applied Genetics, v.126, p.265-274, 2013. Available from: <http://dx.doi.org/10.1007/s00122-012-19793>. Accessed: Sep. 28, 2013, doi: 10.1007/s00122-012-1979-3.

LIU, T.G. et al. First detection of virulence in Puccinia striiformis f. sp. triticiin China to resistance genes $Y r 24(=Y r 26)$ present in wheat cultivars Chuanmai 42. Plant Disease, v.94, p.1163-1163, 2010. Available from: <http:// dx.doi.org/10.1094/PDIS-94-91163C >. Accessed: Sep. 01, 2010, doi: 10.1094/PDIS-94-9-1163C.

PATERSON, A.H. et al. The sorghum bicolor genome and the diversification of grasses. Nature, v.457, p.551-556, 2009. Available from: <http://dx.doi.org/10.1038/nature0772>. Accessed: July. 29, 2009, doi: 10.1038/nature07723.

ROSEWARNE, G.M. et al. Analysis of leaf and stripe rust severities reveals pathotype changes and multiple minor QTLs associated with resistance in an Avocet $\times$ Pastor wheat population. Theoretical and Applied Genetics, v.124, p.1283-1294, 2012. Available from: $<$ http://dx.doi.org/ doi: 10.1007/s00122-012-1786-x>. Accessed: Jan. 25, 2012, doi: 10.1007/s00122-012-1786-x.

SOMERS, D.J. et al. A high-density microsatellite consensus map for bread wheat (Triticum aestivum L.). Theoretical and Applied Genetics, v.109, p.1105-1114, 2004. Available from: <http:/ dx.doi.org/ 10.1007/s00122-004-1740-7>. Accessed: Jan. 29, 2009, doi: 10.1007/s00122-004-1740-7.

WAN, A.M. et al. Wheat stripe rust epidemic and virulence of Puccinia striiformis f. sp. tritici in China in 2002. Plant Disease, v.88, p.896-904, 2004. Available from: <http://dx.doi.org/ 10.1094/ PDIS.2004.88.8.896>. Accessed: Aug. 01, 2004, doi: 10.1094/ PDIS.2004.88.8.896.

WANG, Z.Z. et al. Comparative genetic mapping and genomic region collinearity analysis of the powdery mildew resistance gene Pm41. Theoretical and Applied Genetics, v.127, p.1741-175, 2014. Available from: <http://dx.doi.org/10.1007/s00122-014-23365>. Accessed: Jun. 07, 2014, doi: 10.1007/s00122-014-2336-5.
XIANG, C. et al. Molecular Mapping of Stripe Rust Resistance Gene $\operatorname{Yr} 76$ in Winter Club Wheat Cultivar Tyee. Phytopathology, v.106, p.1186-1193, 2016. Available from: <http://dx.doi.org/10.1094/PHYTO-0116-0045-FI>. Accessed: Apr. 06, 2016, doi: 10.1094/ PHYTO-01-16-0045-FI.

YANIV, E. et al. Evaluation of marker-assisted selection for the stripe rust resistance gene $\mathrm{Yr} 15$, introgressed from wild emmer wheat. Molecular Breeding, v.35, p.1-12, 2015. Available from: $<$ http://dx.doi.org/ 10.1111/pbi.12281>. Accessed: Sep. 22, 2015, doi: $10.1111 /$ pbi.12281.

YANG, Z.M. et al. Situation of the sources of stripe rust resistance of wheat in the post-CY32 era in China. Acta Agronomica Sinica, v.29, p.161-168, 2003. Available from: <http://dx.doi.org/ 10.3321/j.issn:0496-3490.2003.02.001>. Accessed: Jan. 01, 2003 , doi: 10.3321/j.issn: 0496-3490.2003.02.001

ZHAN, H.X. et al. Chromosomal location and comparative genomics analysis of powdery mildew resistance gene Pm51 in a putative wheat-Thinopyrum ponticum introgression line. Plos One, v.9, p.e113455, 2014. Available from: <http://dx.doi.org/ 10.1371/ journal.pone.0113455 >. Accessed: Nov. 21, 2014, doi: 10.1371/ journal.pone. 0113455

ZHAO, L. et al. The dissection and SSR mapping of a hightemperature adult-plant stripe rust resistance gene in American spring wheat cultivar Alturas. European Journal of Plant Pathology, v.134, p.281-288, 2012. vailable from: <http://dx.doi. org/10.1007/s10658-012-9987-3>. Accessed: Apr. 25, 2012, doi: $10.1007 / \mathrm{s} 10658-012-9987-3$

ZHANG, W.J et al. Genetic maps of stem rust resistance gene Sr35 in diploid and gexaploid wheat. Crop Science, v.50, p.2464-2474, 2010. vailable from: <http://dx.doi.org/10.2135/ cropsci2010.04.0202Accessed: Nov. 01, 2010, doi: 10.2135/ cropsci2010.04.0202.

ZHANG, X.J. et al. Fine mapping of wheat stripe rust resistance gene Yr26 based on collinearity of wheat with Brachypodium distachyon and Rice. Plos One, v.8, p.e57885, 2013. vailable from: $<$ http://dx.doi.org/10.1371/journal.pone.0057885>. Accessed: Mar. 05, 2013, doi: 10.1371/journal. pone.0057885. 